\title{
Wood in different stream types: Epixylic biofilm and wood-inhabiting invertebrates in a lowland versus an upland stream
}

\author{
Bernd Spänhoff ${ }^{1,2 *}$ and Ernst Cleven ${ }^{1}$ \\ 1 Department of Limnology, Institute for Evolution and Biodiversity, University of Muenster, Huefferstr. 1, D-48149, Germany \\ 2 Saxon State Agency for Environment, Agriculture and Geology, PO 800132, D-01101 Dresden, Germany
}

Received 30 November 2009; Accepted 15 January 2010

\begin{abstract}
Colonization of incubated wood samples by invertebrates and biofilm was compared between a lowland and an upland stream over a 15 month period. Invertebrate densities increased during the first weeks of incubation and then decreased to rather stable densities during the remaining investigation period in both streams. Within the first incubation weeks invertebrate numbers were significantly higher in the lowland stream. Higher dissolved nutrient concentrations and water temperatures accelerated initial epixylic biofilm development in the lowland stream. Lowest invertebrate numbers on incubated branches in the lowland stream coincided with increased discharge. Extreme low flows in the upland stream resulted in lowest invertebrate numbers on incubated wood during the study. Temporal patterns of biofilm and invertebrates indicated some interactions, but statistical significance was low, which might be caused by the variety of interacting effects. Additionally, invertebrate assemblages of in-stream wood samples were collected from four lowland and four upland streams to examine differences of epixylic invertebrate assemblages between the two stream types. Invertebrate densities were significantly higher on submerged wood from lowland streams than wood from upland streams. However, no clear differences in invertebrate assemblages found between the stream types. The study results show that introduced wood in lowland and upland streams is rapidly colonized by aquatic invertebrates and provided an attachment site for biofilms. Invertebrate numbers during the first two months of incubation significantly overestimate the invertebrate numbers found on resident in-stream wood in lowland and upland streams. Analyses of taxonomic composition of wood-inhabiting invertebrate assemblages from natural wood from lowland and upland streams revealed that each stream displayed a rather specific epixylic fauna.
\end{abstract}

Key words: Epixylic biofilm / wood-inhabiting invertebrates / lowland sand stream / upland gravel stream / wood in streams

\section{Introduction}

The interest in wood in stream ecology increased during recent years. Especially its use in stream restoration (e.g. Kail et al., 2007; Lester and Boulton, 2008) came stronger into scientific focus. Introducing wood into degraded streams might support ecosystem regeneration as it is an important component of pristine stream ecosystems. Submerged wood in streams, represented mainly by medium sized branches with lengths $<100 \mathrm{~cm}$ and diameters $<10 \mathrm{~cm}$ (Elosegi et al., 1999), serves as habitat (Hoffmann and Hering, 2000; Benke and Wallace, 2003)

\footnotetext{
*Corresponding author: bernd. spaenhoff@web.de
}

and food (Pereira et al., 1982) for many invertebrate species. It provides a carbon source for wood-degrading bacteria and fungi (Gulis et al., 2008) and, finally, provides an attachment site for epixylic biofilm (Sinsabaugh et al., 1991; Sabater et al., 1998; Spänhoff et al., 2006) that serves as additional food source for invertebrates (Eggert and Wallace, 2007).

Woody debris, moreover, is a source of fine organic matter and thus enriches the microbial and macrobial food webs of streams equally (Ward and Aumen, 1986). Abundance (Collier and Halliday, 2000; Johnson and Kennedy, 2003) and secondary production (Benke et al., 1984) of aquatic invertebrates inhabiting woody debris can be significantly higher than those colonizing sand 
and mud habitats. Furthermore, the standing stock of woody debris in forest streams can reach and sometimes exceed the standing stock of leaf litter (Magana and Bretschko, 2003), stressing the importance of woody debris as a major carbon source (Elosegi et al., 2007). However, the importance of wood is more pronounced in sandy lowland streams dominated by unstable fine sediments compared to upland gravel streams with stable bed sediments (Collier, 2004). Lowland sand and upland gravel streams differ in many physical properties like morphology, substrate stability, flow and hydraulics (Giller and Malmqvist, 1998). Thus, submerged branches represent stable habitats for invertebrates (Hax and Golladay, 1998) and primary producers (Atkinson et al., 2008) in sandy lowland streams. In contrast, submerged wood is rather unstable and can be rapidly transported downstream or laterally to the floodplain in fast flowing upland streams with coarse bed sediments (Webster et al., 1999; Millington and Sear, 2007).

The aim of the present study was to compare the colonization of experimentally submerged alder branches (Alnus glutinosa) by aquatic invertebrates and epixylic biofilms over a 15 month period in a sandy lowland stream as well as in a gravel upland stream. Sand substrates of lowland streams are mainly colonized by collector/ gatherers. Woody debris is often the only hard substrate in sandy lowland streams and therefore serves as preferred attachment site for algal biofilms, the main food of grazing invertebrates. In upland streams biofilm grow on gravel and cobble sediments surfaces providing the main food source for grazers. Leaf litter is only seasonally abundant in many streams and can be washed out rapidly by spates, especially when natural retention is low due to morphological degradation (e.g. incision and straigthening of streams). Thus, woody debris might be the only year-round available food source for shredders and other invertebrates feeding on CPOM. Due to the differences in substrate composition between the two stream types we expected higher maximum numbers of invertebrates and higher proportions of opportunistic sediment feeders on submerged wood in lowland streams, while grazers were expected to dominate epixylic assemblages in upland streams. Additionally, we expected faster epixylic biofilm growth on submerged branches in the sandy lowland stream due to the lower flow velocity and higher concentrations of dissolved nutrients.

To set the results of the incubation experiment into a wider ecological context, we collected in-stream woody debris once during fall from four sandy lowland and four gravel upland streams. The wood-inhabiting invertebrates of these streams had been investigated during spring in a previous study (Homermann, 2001). Wood samples were used to analyse the wood-inhabiting invertebrate fauna for general differences as well as to compare the fauna of experimentally submerged wood to natural wood samples that might had been submerged for several years and represents the resident epixylic invertebrate fauna.

\section{Material and methods}

\section{Study sites}

The incubation experiment was conducted in two streams in Northrhine-Westphalia, Germany (Fig. 1). The Ladberger Muehlenbach (LMB) is a 3rd-order lowland stream (lat. $52^{\circ} 77^{\prime} 38^{\prime \prime} \mathrm{N}$, long. $7^{\circ} 52^{\prime} 48^{\prime \prime} \mathrm{E}$ ). Its water is enriched with nutrient-rich drainage water from agricultural non-point sources. Riparian vegetation of the sampling site consists of black alder (Alnus glutinosa) and several oak species, mainly common oak (Quercus robur). The main substrate of the stream is sand with a mean grain size of 165 to $270 \mu \mathrm{m}$ depending on the sediment depth (Cleven, 1999). The Loermecke (LOER) is a 3rd-order gravel stream in the upland region of the Sauerland (lat. $51^{\circ} 26^{\prime} 50^{\prime \prime} \mathrm{N}$, long. $8^{\circ} 22^{\prime} 15^{\prime \prime} \mathrm{E}$ ). Its water is unpolluted by agricultural drainages, however, its upstream section flows through plantations of Norway spruce (Picea abies). The sampling site is bounded by natural deciduous tree vegetation dominated by black alder and willow species (Salix spp.). Both sampling sites displayed a rather nearto-natural channel morphology and riparian vegetation.

Concentrations of dissolved nutrients (nitrate, nitrite, ammonium, and ortho-phosphate) in water samples from the two study sites were analysed at every sampling date in the laboratory using common photometric analyses (Cleven and Meyer, 2003); chlorophyll $a$ was measured following Nusch et al. (1999). Specific conductivity, pH, oxygen saturation, and concentrations of dissolved oxygen were measured at every sampling date in situ using transportable field probes (WTW Weilheim, Germany); flow velocities (min. and max.) near the branches by a "Mini air 2" flow meter. Data on physical parameters and water chemistry for the two streams are given in Table I. Discharge regime of the two streams at the sampling sites was calculated by using data from nearby gauge stations (Fig. 2). These continuously measured data from the gauge stations were regressed with discharge measurements of each sampling date from the study sites.

To characterize resident wood-inhabiting invertebrate assemblages, samples of in-stream submerged branches were taken from four upland gravel streams (altitudes 220-400 m a.s.1.): Bieberbach (B), Große Schmalenau (S), Heve $(\mathrm{H})$, Loermecke $(\mathrm{L})$ and four lowland sand streams (altitudes 50-80 m a.s.1.): Vechte (V), Gauxbach (GX), Eltingmuehlenbach (E), and Gellenbach (GB) in fall 2001 (Fig. 1). The sampling sites of the in-stream wood samples were chosen due to near-to-natural riparian vegetation and stream morphology. All sites were visually comparable to the two sites of the long-term incubation experiment (described before) in terms of flow velocity, sediment conditions and riparian vegetation.

\section{Preparation of experimental substrata}

Alder branches (Alnus glutinosa) were collected from a fallen tree that displayed no signs of advanced 


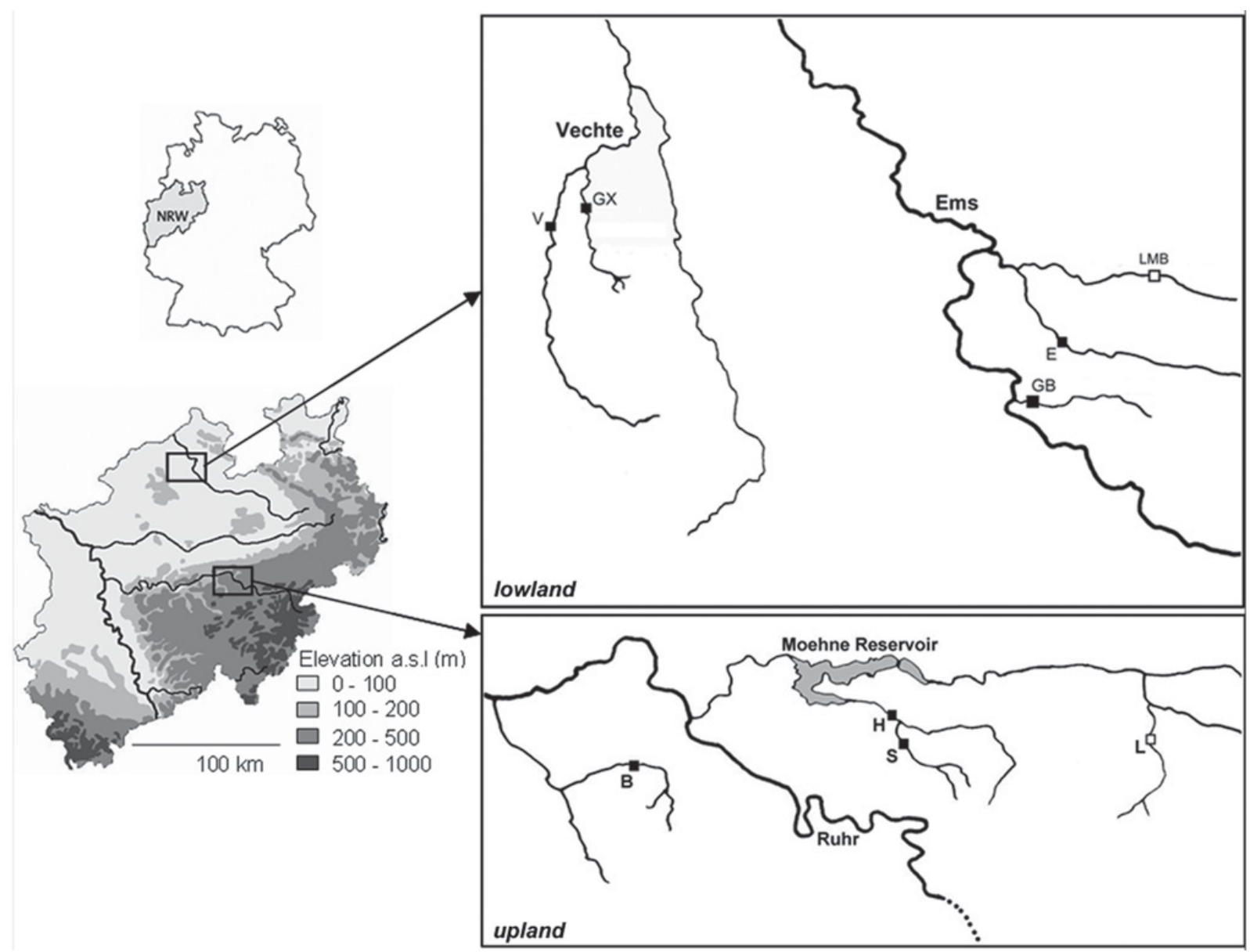

Fig. 1. Study sites of the incubation experiment (open symbols) and in-stream wood samples (closed symbols) in NorthrhineWestphalia (NRW), Germany. The upland study sites (L) for the incubation experiment and in-stream wood samples were identical. ( $\mathrm{L}=$ Loermecke, $\mathrm{B}=$ Bieberbach, $\mathrm{H}=$ Heve, $\mathrm{S}=$ Große Schmalenau, $\mathrm{GX}=$ Gauxbach, $\mathrm{V}=$ Vechte, $\mathrm{E}=$ Eltingmuehlenbach, $\mathrm{GB}=$ Gellenbach).

Table I. Physical and chemical characteristics of water from the two streams during the study period (mean \pm SD are presented). Temperature was measured continuously by data logger and flow velocity (both min. and max.) near the wood samples. Grain size of sediments were analysed once $(N=3)$. All other parameters were measured at the sampling dates incl. the start day of the experiment $(N=11)$.

\begin{tabular}{|c|c|c|}
\hline & Ladberger Muehlenbach & $\overline{\text { Loermecke }}$ \\
\hline Discharge (L.s $\left.{ }^{-1}\right)$ & $271 \pm 133$ & $157 \pm 108$ \\
\hline Flow velocity $\left(\mathrm{cm}^{\mathrm{s}} \mathrm{s}^{-1}\right)$ & $20-30$ & $30-100$ \\
\hline Proportion of grain size $>1 \mathrm{~cm}(\%)$ & $0.3 \pm 0.1$ & $96.7 \pm 3.3$ \\
\hline Temperature $\left({ }^{\circ} \mathrm{C}\right)$ & $0.2-25.2$ & $-0.5-19.2$ \\
\hline Conductivity $\left(\mu \mathrm{S} . \mathrm{cm}^{-1}\right)$ & $573 \pm 25$ & $107 \pm 27$ \\
\hline $\mathrm{pH}$ & $7.7 \pm 0.2$ & $7.2 \pm 0.3$ \\
\hline Oxygen concentration $\left(\mathrm{mg} \cdot \mathrm{L}^{-1}\right)$ & $10.8 \pm 1.4$ & $11.4 \pm 1.2$ \\
\hline Oxygen saturation $(\%)$ & $83.7 \pm 29.4$ & $96.6 \pm 3.9$ \\
\hline $\mathrm{NH}_{4}-\mathrm{N}\left(\mathrm{mg} . \mathrm{L}^{-1}\right)$ & $0.10 \pm 0.08$ & $0.02 \pm 0.02$ \\
\hline $\mathrm{NO}_{2}-\mathrm{N}\left(\mathrm{mg} \cdot \mathrm{L}^{-1}\right)$ & $0.06 \pm 0.02$ & $0.01 \pm 0.005$ \\
\hline $\mathrm{NO}_{3}-\mathrm{N}\left(\mathrm{mg} \cdot \mathrm{L}^{-1}\right)$ & $7.37 \pm 2.29$ & $0.96 \pm 0.48$ \\
\hline $\mathrm{PO}_{4}-\mathrm{P}\left(\mathrm{mg} \cdot \mathrm{L}^{-1}\right)$ & $0.12 \pm 0.02$ & $0.02 \pm 0.01$ \\
\hline Chlorophyll $a\left(\mu \mathrm{g} . \mathrm{L}^{-1}\right)$ & $8.2 \pm 7.7$ & $1.1 \pm 0.5$ \\
\hline
\end{tabular}

decomposition. Branches were trimmed to different lengths depending on the branch diameter to obtain equally sized surfaces. Mean length of the branches was
$25.3 \mathrm{~cm}$, mean diameter $5.0 \mathrm{~cm}$ and surface areas ranged from 336.6 to $558.3 \mathrm{~cm}^{2}$ (calculated using the formula for cylinders). All branches were covered by a fissured bark. 
Alder was chosen because it is the most common tree species along both stream channels; the use of a single wood species provided uniform start conditions.

Ten branches were fastened to metal rods using polyester threads. The wood bearing metal rod was fixed by a laboratory clamp horizontally to another metal rod forming a T-shaped construction. Overall, six constructions were placed every 15 to $20 \mathrm{~m}$ into the bed sediment of the streams until the tied branches lay on the sediment surface to enable invertebrate colonization by passive drift and active movement. The branches were incubated in a $100 \mathrm{~m}$ long section of the lowland stream (LMB) on 18 October 2000 and in the upland stream (Loermecke) two days later. Five replicates per stream were taken after $14,34,55,83,139,202,250,320,390$, and 593 days of incubation.

\section{Sampling of biofilm components from incubated branches}

Three replicates of the surface biofilm were taken per branch for chlorophyll $a(\operatorname{chl} a)$ and ATP analyses. Chl $a$ was used to indicate algal biomass of the epixylic biofilm, whereas ATP has been used to indicate total biomass of microbial (Golladay and Sinsabaugh, 1991; Sinsabaugh et al., 1991). Each biofilm subsample was scraped from an area of $2 \mathrm{~cm}^{2}$ using a scalpel. Extraction of chl $a$ was performed by the hot ethanolic extraction method following Nusch (1999). ATP analyses were performed with test kits (ConCell, Nettetal, Germany) as described in Spänhoff et al. (2006).

\section{Sampling of invertebrates}

Five branches were collected at random from different fixing device constructions at each sampling date by cutting the fastening thread. Each branch was collected in a sampling net (mesh size $63 \mu \mathrm{m}$ ), which was held behind the branch to catch drifting invertebrates and fine particulate matter washed from the branch surface. Branch and the content of the sampling net were collected in a freeze bag filled with stream water and taken to the laboratory. There, each branch was carefully washed several times under a forced water jet into a sieve ( $63 \mu \mathrm{m}$ mesh size) to collect the wood-inhabiting invertebrates. These were picked from the sieve and preserved in $70 \%$ ethanol. The remaining fine particulate matter (FPM) was preserved in $98 \%$ ethanol, and smaller invertebrates were sorted out from the FPM under a stereomicroscope at $16 \times$ to $40 \times$ magnification. The branches were inspected also under a stereomicroscope to detect remaining invertebrates. Mainly invertebrates that build fixed retreatments on wood surfaces (some chironomids, Lype spp., Hydropsyche spp.) were found. The proportion of functional feeding groups was calculated for the invertebrate assemblage of both sampling sites for each sampling date according to Schmedtje and Colling (1996).
Naturally submerged wood was collected by cutting pieces of $30-40 \mathrm{~cm}$ length underwater from submerged branches using a branch shear. A sweep net (63 $\mu \mathrm{m}$ mesh) was held behind the wood samples to catch drifting invertebrates. Each sample was carefully put in a stream water filled freeze bag and transferred to the laboratory for further processing. Sampling of invertebrates was identically performed as described before for the incubated wood samples. Prior to finally collect wood-boring invertebrates, length and diameter of each branch were measured to calculate the surface area and a small slice (whole stick diameter, $c a$. 3-5 cm length) was cut off for analysing the density of wood as a measure of its decay stage according to Spänhoff et al. (2001). Decay stage might be an important factor for specialized xylophagous invertebrate species. The rest of the branch was examined for wood-boring invertebrates by carefully crumbling the wood using a knife and forceps. All invertebrates were identified to the lowest possible taxonomic level, mainly genus or species, except oligochaets and chironomids that were identified to family or tribus level.

\section{Statistical analyses}

Data of chl $a$ and ATP were square-root-transformed to obtain normal distributions. Invertebrate abundances were extrapolated to squaremeter using the surface area of each particular branch and $\log 10$-transformed to obtain normal distribution for statistical analysis. Invertebrate assemblages and concentrations of biofilm parameters of incubated branches were tested for significant differences between sampling dates in each stream and for the effect of stream type as well as the interactive effect of the two factors by a multivariate general linear model. Fixed factors were stream type and days of incubation. StudentNewman-Keuls (SNK) post-hoc tests were used to detect significant differences between sampling days for invertebrates and biofilm parameters. Statistical analyses were performed using SPSS 11.5 software. Faunal differences between all incubated wood samples were analysed by a detrended component analysis (DCA) using the software Canoco for Windows 4.5.

Invertebrate assemblages of naturally submerged instream wood were also analysed by a detrended component analysis (DCA) with downweighting of rare species. Differences between abundances of epixylic invertebrates from the two stream types (lowland vs. upland) were analysed by an independent samples T-test.

To compare epixylic invertebrate numbers of incubated vs. in-stream wood, we grouped the invertebrate abundances of the first three (days 14, 34, 55) and last three (days 320, 390, 593) sampling dates of the incubation experiment into "early" and "late" colonization stages. These two stages were analysed together with all samples of the in-stream wood by an univariate ANOVA with invertebrate abundances as dependent variable and stream type and stage of colonization ("early", "late" for incubated and "old" for in-stream wood) as fixed factors. 
Table II. Summary of multivariate general linear model analyses for the effect of stream type and days of incubation and the interactive effects of the two factors on ATP and chl $a$ concentrations of epixylic biofilms and invertebrates on incubated branches.

\begin{tabular}{|c|c|c|c|c|c|}
\hline Independent variable & Dependent variable & Type III SS & d.f. & $F$-statistic & $P$-value \\
\hline \multirow[t]{3}{*}{ Stream type } & ATP & 0.025 & 1 & 7.13 & 0.010 \\
\hline & Chlorophyll $a$ & 0.317 & 1 & 2.86 & 0.096 \\
\hline & Invertebrates & 0.423 & 1 & 7.78 & 0.007 \\
\hline \multirow[t]{3}{*}{ Days of incubation } & ATP & 0.012 & 9 & 3.38 & 0.002 \\
\hline & Chlorophyll $a$ & 0.351 & 9 & 3.16 & 0.004 \\
\hline & Invertebrates & 0.620 & 9 & 11.40 & $<0.001$ \\
\hline \multirow{3}{*}{ Stream type $\times$ days of incubation } & ATP & 0.007 & 9 & 2.05 & 0.049 \\
\hline & Chlorophyll $a$ & 0.234 & 9 & 2.11 & 0.043 \\
\hline & Invertebrates & 0.310 & 9 & 5.71 & $<0.001$ \\
\hline
\end{tabular}

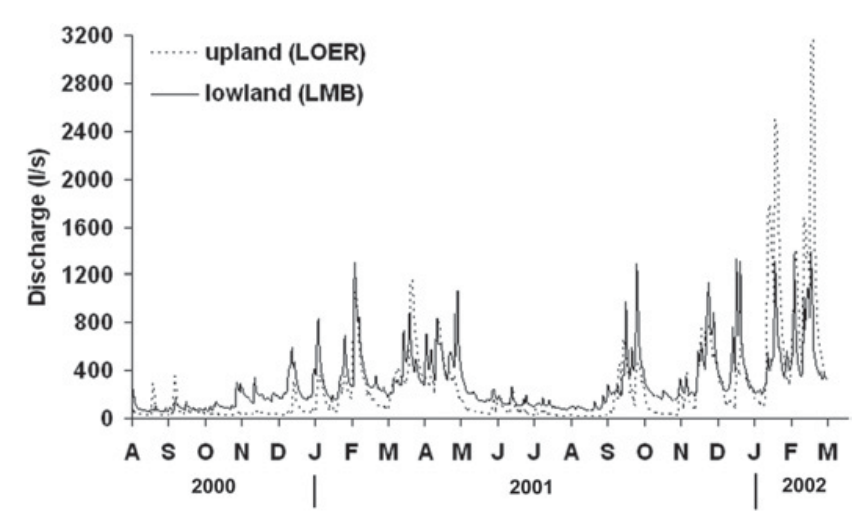

Fig. 2. Discharge regime of the study sites of the two streams during the incubation experiment.

To detect differences between stages of invertebrate colonization a Tukey's honestly significant difference post-hoc test was performed.

\section{Results}

\section{Biofilm development on experimentally submerged wood}

Development of epixylic biofilms analysed by chl $a$ and ATP displayed different temporal patterns for both parameters and streams (Figs. 3a and 3b). While chl $a$ concentrations steadily decreased in the Loermecke during the first five sampling dates, chl $a$ mainly increased in the LMB. Epixylic algal biofilm in the LMB displayed significantly higher chl $a$ concentrations in comparison to wood incubated in the Loermecke on some sampling dates. Concentrations of chl $a$ in surface scrapings peaked in May in both streams $\left(2.32 \mu \mathrm{g} . \mathrm{cm}^{-2}\right.$ in the LMB and $1.57 \mu \mathrm{g} . \mathrm{cm}^{-2}$ in the Loermecke; Fig. 3a), thereafter decreased to $0.54 \mu \mathrm{g} . \mathrm{cm}^{-2}$ in the LMB and $0.82 \mu \mathrm{g} . \mathrm{cm}^{-2}$ in the Loermecke and finally remained on these levels until the end of the study period.

To estimate microbial biomass in epixylic biofilms concentrations of ATP were measured. ATP showed similar temporal variations in the two streams with an initial increase for 139 days and a following decrease during the summer months June and July (Fig. 3b). However, in the Loermecke ATP concentrations peaked with $0.19 \mu \mathrm{g} . \mathrm{cm}^{-2}$ and decreased to $0.05 \mu \mathrm{g} . \mathrm{cm}^{-2}$ until the following sampling date. Epixylic biofilms from the LMB displayed a first ATP peak after 139 days of incubation as well $\left(0.14 \mu \mathrm{g} . \mathrm{cm}^{-2}\right)$, but remained constant during the following sampling dates. Maximum concentrations were reached after 320 days in September $\left(0.19 \mu \mathrm{g} . \mathrm{cm}^{-2}\right)$. Until the end of the study period dynamics of ATP concentrations in surface srapings were rather identical in both streams as displayed by almost parallel graphs after the 6th sampling date in Figure 3b.

Multivariate general linear model displayed significant effects of days of incubation for ATP and chla $a$ concentrations. The effect of stream type was significant for ATP but not for chl $a$. Additionally, the interaction of stream type and days of incubation affected significantly ATP concentrations and chl $a$ (Tab. II).

\section{Invertebrate colonization of experimentally submerged wood}

Wood-inhabiting invertebrate numbers peaked in both study streams after the first three months of incubation, then they decreased and showed significant fluctuations during the rest of the study period. Numbers were generelly higher in the LMB than those of the Loermecke with the exception of two sampling dates (Fig. 4). Invertebrate numbers ranged between max. $34140 \pm 8120$ ind. $^{-2}$ and $\min .2903 \pm 754$ ind. $\mathrm{m}^{-2}$ in the $\mathrm{LMB}$, whereas the range in the Loermecke was between max. $18887 \pm$ 3275 ind. $\mathrm{m}^{-2}$ and $1409 \pm 654$ ind. $\mathrm{m}^{-2}$. Statistical analyses by the multivariate general linear model with subsequent post-hoc test revealed a more fluctuating temporal dynamic of invertebrate colonization in the LMB compared to the Loermecke (Fig. 4). Furthermore, invertebrate numbers were significantly affected by stream type, days of incubation and the interaction of the two factors (Tab. II).

Chironomids were the main colonizers of woody debris in both streams, accounting sometimes up to $90 \%$ of the wood-inhabiting invertebrate assemblages. Orthocladiinae 


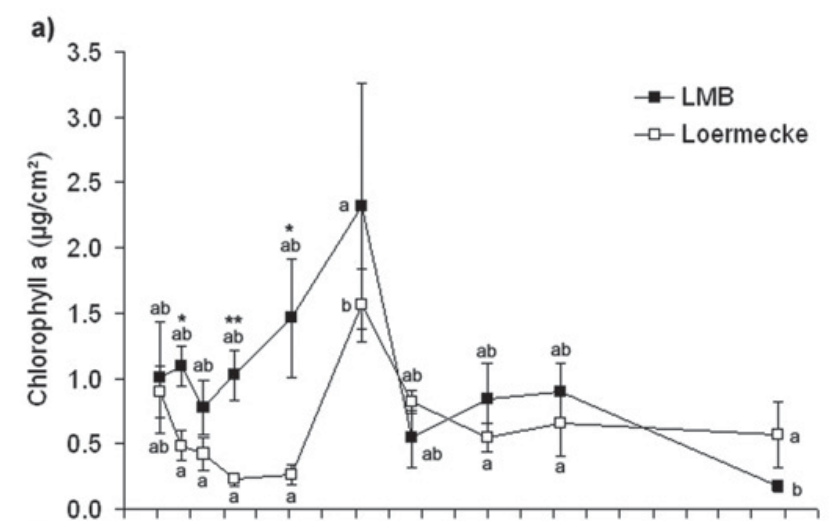

b)

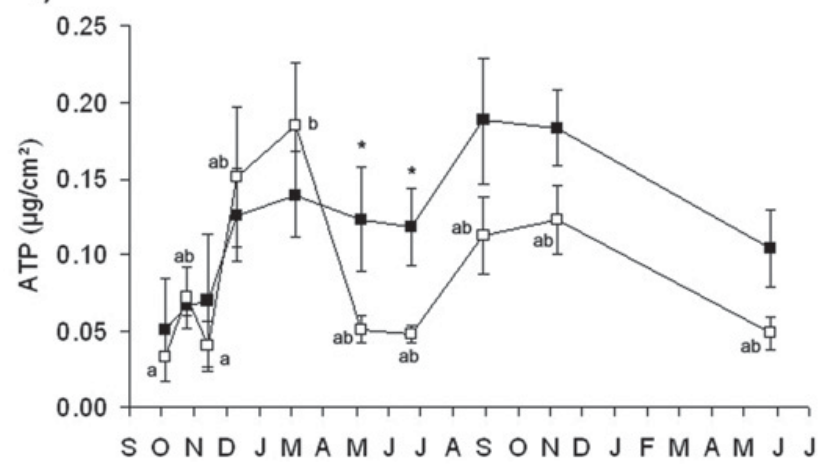

Fig. 3. Temporal dynamics of $\operatorname{chl} a$ and ATP concentrations of epixylic biofilms from the study streams $(\mathrm{LMB}=$ lowland; Loermecke $=$ upland $)$. Asterisks denote significant differences between the two streams on the same sampling date $(* p<0.05$; ** $p<0.01)$. Different letters indicate significant differences bewteen sampling dates in the particular stream $(p<0.05)$, no differences of ATP concentrations were detected in the LMB.

was the dominant subfamily of the chironomid community in both streams $(51 \%$ in the LMB, $77 \%$ in the Loermecke). Chironomini and Tanytarsini reached much higher numbers in the lowland stream whereas Tanypodinae were more numerous on wood in the upland stream.

Multivariate statistics displayed distinct differences between the wood-colonizing invertebrate assemblages of the two streams. Results of the DCA showed all sampling dates from the LMB and the Loermecke spatially separated along the first axis that explained $41.0 \%$ of the variance of species data (Fig. 5). The second axis explained only $7.9 \%$ of the variance of species data and separated the sampling dates by the mean number of invertebrates found on the incubated branches. Thus, main difference between wood-inhabiting invertebrate assemblages was explained by the stream type and to some extent by the duration of incubation.

Composition of functional feeding groups was also distinctly different between the two invertebrate assemblages. Grazers represent the dominant feeding group on woods incubated in the Loermecke, whereas collector/ gatherer and grazer were dominant in the LMB (Fig. 6). Proportion of predators, mainly small predatory Diptera

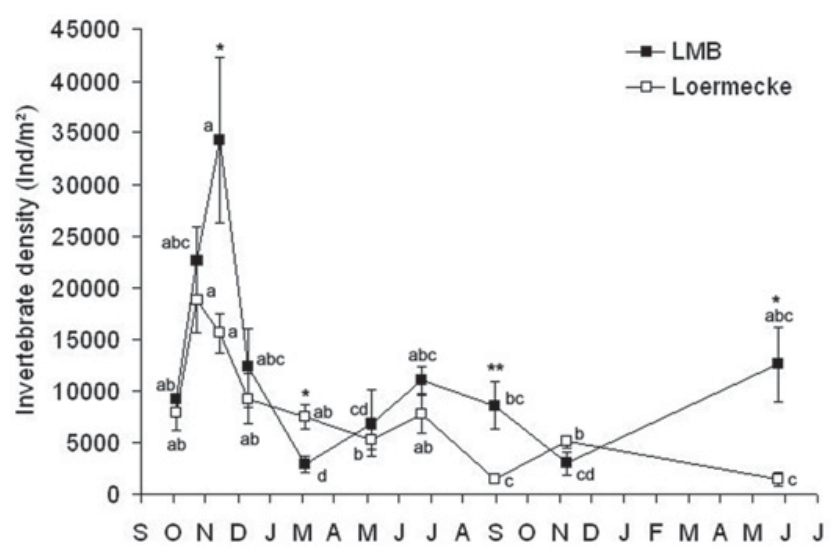

Fig. 4. Temporal dynamics of epixylic invertebrates from the study streams $(\mathrm{LMB}=$ lowland; Loermecke $=$ upland $)$. Asterisks denote significant differences between the two streams on the same sampling date $(* p<0.05 ; * * p<0.01)$. Different letters indicate significant differences bewteen sampling dates in the particular stream $(p<0.05)$.

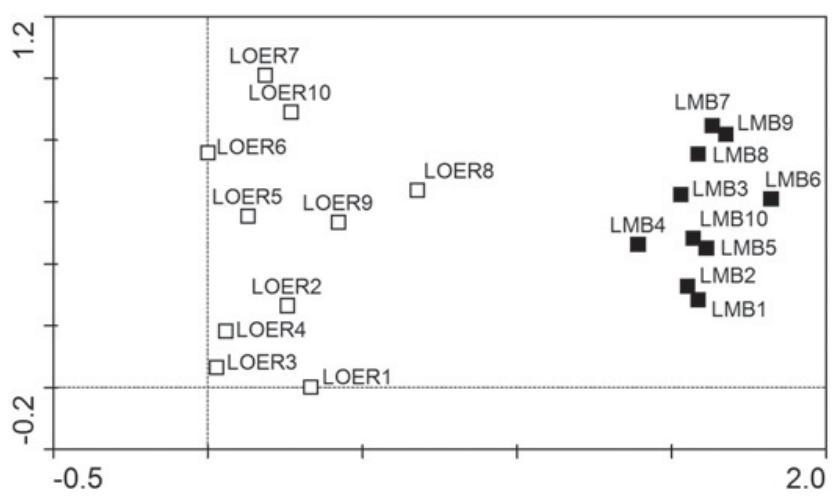

Fig. 5. DCA of invertebrate assemblages from all sampling dates (numbers indicate the time series of samples) of both streams (upland: $\mathrm{LOER}=$ Loermecke, lowland: $\mathrm{LMB}=$ Ladberger Muehlenbach).

(Empididae) and Hydrachnidia, became remarkably high on two sampling dates in the Loermecke when total abundances of invertebrates were low. Oligochaets were the main collector/gatherer in the LMB. Numbers of filterer, mainly Tanytarsini and hydropsychid caddisfly larvae, were higher on the wood surfaces from the LMB compared to the Loermecke. Shredders were generally less abundant in both streams, however, they reached higher numbers during the summer months in the LMB. Finally, the proportion of shredders remained relatively constant on woods from the Loermecke $(2.3-7.5 \%)$ during the whole study period (Fig. 6).

\section{Wood-inhabiting invertebrates of naturally submerged in-stream wood}

Invertebrate numbers differed distinctly between the streams with significantly lower abundances on submerged 
Table III. Invertebrate abundances (ind. $\mathrm{m}^{-2}$, mean $\pm \mathrm{SD}, N=5$ ) and proportion (\%) of taxonomic groups on in-stream wood samples from upland and lowland streams. Significant differences bewteen lowland and upland streams were denoted by * $(p<0.01)$. (Oth. $=$ Others incl. Nematoda, Plathelminthes, Hirudinea, Megaloptera, Moll. = Mollusca, Oligo. = Oligochaeta, Crust. $=$ Crustacea,$\quad$ Eph. $=$ Ephemeroptera,$\quad$ Plec. $=$ Plecoptera,$\quad$ Col. $=$ Coleoptera,$\quad$ Trich. $=$ Trichoptera,$\quad$ Dip. $=$ Diptera.$)$ Abbrevations for the streams are given in Methods.

\begin{tabular}{|c|c|c|c|c|c|c|c|c|c|c|c|}
\hline Streams & Invertebrates & Oth. & Moll. & Oligo. & Crust. & Acari & Eph. & Plec. & Col. & Trich. & Dip. \\
\hline Upland & $1723 \pm 206$ & & & & & & & & & & \\
\hline B & $2068 \pm 268$ & 7.7 & 0.4 & 7.1 & 2.5 & 3.7 & 4.9 & 1.3 & 0.2 & 3.0 & 69.1 \\
\hline $\mathrm{S}$ & $2263 \pm 646$ & 0.2 & 0.3 & 9.9 & 0.1 & 9.9 & 2.8 & 2.0 & 14.2 & 4.1 & 56.6 \\
\hline $\mathrm{H}$ & $1582 \pm 267$ & 1.0 & 0.2 & 16.5 & 0.0 & 6.4 & 9.0 & 3.6 & 3.3 & 17.9 & 42.2 \\
\hline $\mathrm{L}$ & $980 \pm 185$ & 0.0 & 0.0 & 11.1 & 0.0 & 2.3 & 1.7 & 26.1 & 1.2 & 1.0 & 56.6 \\
\hline Lowland & $5533 \pm 1096^{*}$ & & & & & & & & & & \\
\hline V & $7669 \pm 1742$ & 0.1 & 0.0 & 15.5 & 0.9 & 5.9 & 1.2 & 0.0 & 2.7 & 14.7 & 59.2 \\
\hline GX & $10422 \pm 2518$ & 0.0 & 0.0 & 7.9 & 0.1 & 1.0 & 0.1 & 3.2 & 0.2 & 3.4 & 84.1 \\
\hline $\mathrm{E}$ & $2094 \pm 490$ & 8.5 & 0.3 & 40.1 & 2.4 & 8.9 & 6.9 & 0.1 & 3.1 & 15.0 & 14.7 \\
\hline GB & $1949 \pm 542$ & 9.0 & 19.9 & 2.9 & 18.2 & 16.8 & 0.4 & 0.0 & 3.2 & 5.6 & 24.0 \\
\hline
\end{tabular}

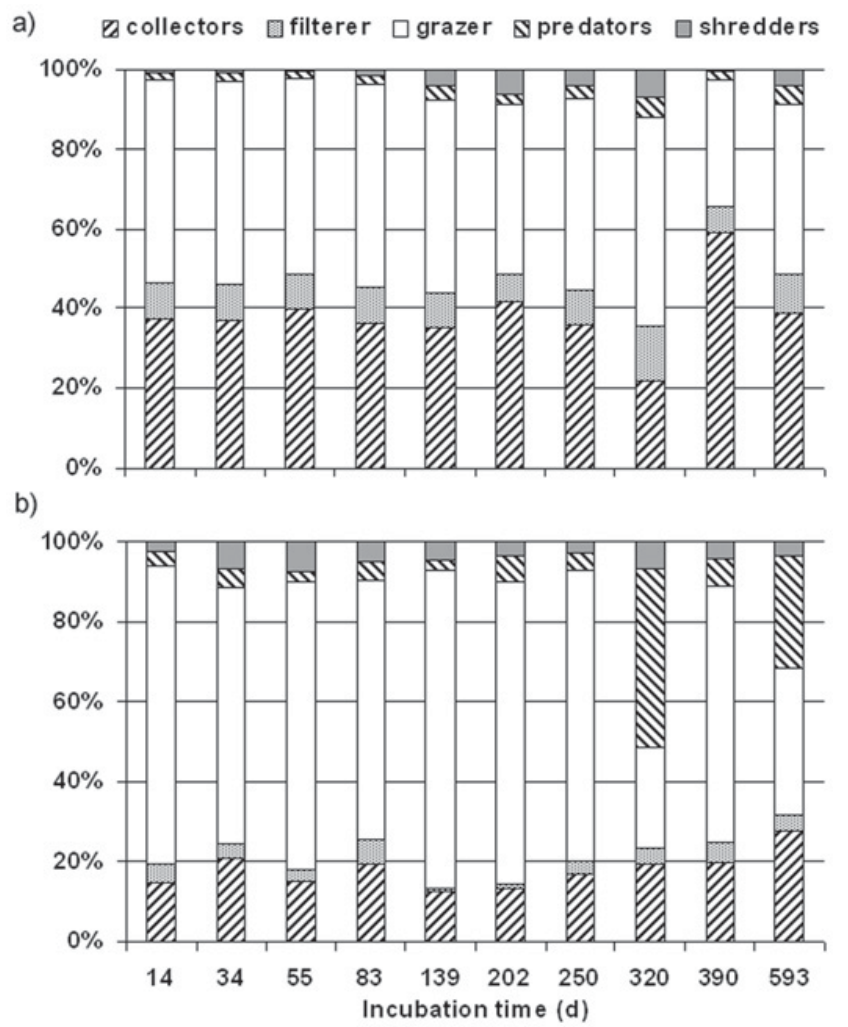

Fig. 6. Functional feeding groups of epixylic invertebrate assemblages on each sampling date from the a) lowland (LMB) and b) upland (Loermecke) stream during the incubation experiment.

wood collected from upland streams (Tab. III). Lowest numbers of invertebrates ranging from 594 ind. ${ }^{-2}$ to 1482 ind. $\mathrm{m}^{-2}$ were found on in-stream wood from the Loermecke, which is in contrast to the much higher numbers shortly after the start of the incubation experiment, but very similar to the numbers of invertebrates towards the end of the incubation experiment (see Fig. 4).

Variability of invertebrate assemblages between samples from one and the same stream were mainly low.

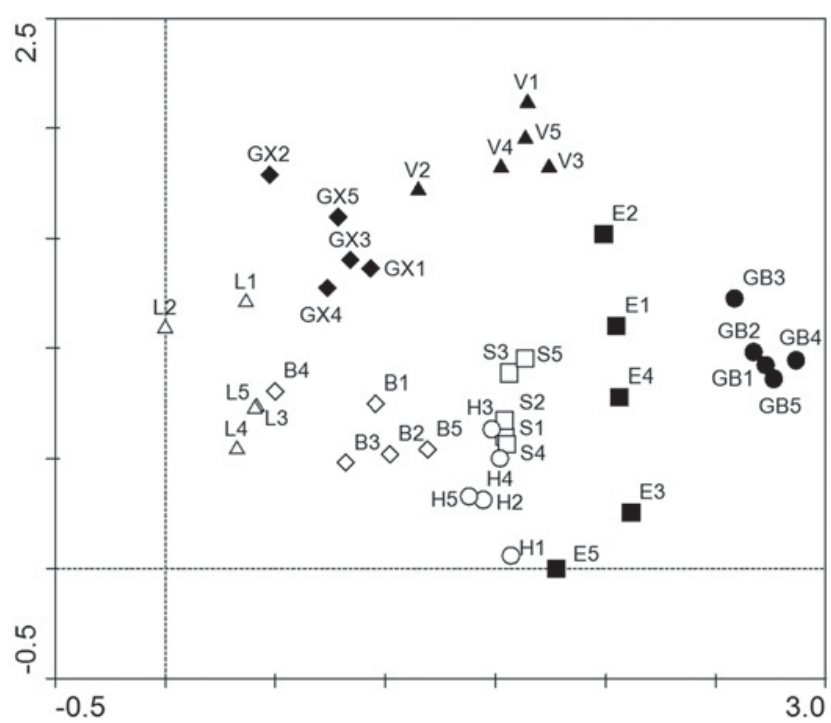

Fig. 7. DCA of invertebrate assemblages from all in-stream wood samples. Open symbols display upland streams $(\mathrm{L}=$ Loermecke, $\mathrm{B}=$ Bieberbach, $\mathrm{H}=$ Heve, $\mathrm{S}=$ Große Schmalenau), closed symbols display lowland streams $(\mathrm{GX}=$ Gauxbach, $\mathrm{V}=$ Vechte, $\mathrm{E}=$ Eltingmuehlenbach, $\mathrm{GB}=$ Gellenbach).

However, no clear differences between epixylic invertebrate assemblages of upland versus lowland streams could be detected by multivariate statistics (Fig. 7). Results of the DCA explained only $11.7 \%$ of the variance of species data by the first and $7.9 \%$ by the second axis, stressing the heterogeneity of the samples. Taxonomic composition of invertebrate assemblages was different between streams of the same type (lowland and upland). Diptera (mainly Chironomidae) were the dominant group on all wood samples from upland streams, however, differences within other insect and non-insect groups were common. While Coleoptera made up to $14 \%$ of the invertebrates on woods from the Große Schmalenau (S), they were negligible within the epixylic fauna of the Heve $(\mathrm{H})$, Loermecke (L) and Bieberbach (B). In these streams other groups, such as Plecoptera or Trichoptera, were more dominant (Tab. III). 
Table IV. Summary of the univariate ANOVA on the effect of stream type, stage of colonization ("early" and "late" for incubated branches, "old" for in-stream wood), and their interactions on the numbers of wood-inhabiting invertebrates found on incubated and resident in-stream branches from upland and lowland streams.

\begin{tabular}{|c|c|c|c|c|}
\hline Independent variable & Type III SS & d.f. & $F$-statistic & $P$-value \\
\hline Stream type & 0.912 & 1 & 6.57 & 0.012 \\
\hline Stage of colonization & 11.741 & 2 & 42.34 & $<0.001$ \\
\hline Stream type $\times$ stage of colonization & 0.353 & 2 & 1.27 & 0.286 \\
\hline
\end{tabular}

Samples from the Eltingmuehlenbach (E) displayed high proportions of oligochaets. Gellenbach (GB) samples yield high numbers of the gastropod Potamopyrgus antipodarum, the amphipod Gammarus pulex and water mites (Tab. III).

Truly xylophagous species that bore into deeper wood layers were found only occasionally in branches with softened surface and densities lower than 0.4 (density of branches ranged from 0.15 , representing wood in advanced state of decay, to 0.56 , representing almost undecayed wood). Wood boring invertebrates were the chironomids Stenochironomus sp. and Symposiocladius lignicola, as well as the limoniid Lipsothrix sp. The xylophagous larvae of the caddisfly Lype spp. were found in all streams without preferences for distinct decay stages of wood but in higher numbers on wood from lowland streams.

Although significance of the multivariate statistics was rather weak, similarity between invertebrate communities of neighbouring streams was higher than between more distant streams. Among lowland wood-inhabiting invertebrate assemblages from the Große Schmalenau (S) and Heve $(\mathrm{H})$ displayed highest similarity among the upland streams (Fig. 7). The other streams were characterised by more specific invertebrate assemblages, however, the Eltingmuehlenbach (E) showed the highest variability of invertebrate assemblages between the samples (Fig. 7).

Finally, the numbers of invertebrates inhabiting instream wood were significantly lower than the abundances of invertebrates found on incubated branches during the first two months $(p<0.001$, Tukey's honestly significant difference post-hoc test). No significant differences $(p=0.618)$ could be detected between in-stream wood inhabiting invertebrates and the abundances found on incubated branches after approximately one year of incubation (Tab. IV).

\section{Discussion}

\section{Epixylic biofilm development on incubated alder branches}

Driving factors of periphyton biofilm dynamics in streams reported so far were light availability and water temperature (Kiffney et al., 2003), dissolved nutrient concentrations (Tank and Dodds, 2003), grazing by invertebrates (Eggert and Wallace, 2007) and moving sediments that abrades periphyton during peak flow events (Biggs et al., 1999). Epixylic biofilms in both study streams reached maximum concentrations of chl $a$ in May when temperature became warmer and sun light reached the stream bottom as canopy was not fully closed, yet. Higher concentrations of dissolved nutrients in the lowland stream enabled a faster initial algal growth in epixylic biofilms. Nevertheless, chl $a$ values were not significantly different between the streams after 139 days of incubation, when other factors, like shading, grazing by invertebrates, sedimentation of sand and abrasion, likely controlled the biofilm development in the two streams.

Studies measuring chl $a$ from biofilms on experimentally submerged branches are rare as often standardized wood surrogates like blocks, veneers or dowels were used. Chl $a$ values reported in studies using wood surrogates ranged from a mean value of $0.09 \mu \mathrm{g} . \mathrm{cm}^{-2}$ (Robertson et al., 2001) to $86.4 \mu \mathrm{g} . \mathrm{cm}^{-2}$ (Bond et al., 2006). In both studies blocks of red gum (Eucalyptus camaldulensis) were experimentally introduced in Australian streams. Bowen et al. (1998) introduced branches for 52 weeks in the littoral of two lakes in Canada and measured mean epixylic chl $a$ concentrations between $c a .0 .45 \mu \mathrm{g} . \mathrm{cm}^{-2}$ and $12.5 \mu \mathrm{g} . \mathrm{cm}^{-2}$ (both values were estimated from a figure). Chl $a$ values from epixylic biofilms of pine branches incubated into the Ladberger Muehlenbach ranged from $0.18 \mu \mathrm{g} . \mathrm{cm}^{-2}$ after 487 days to $1.45 \mu \mathrm{g} . \mathrm{cm}^{-2}$ after 202 days (Spänhoff et al., 2006), corresponding well to the range found in the present study. However, chl $a$ concentrations of epixylic biofilms in the present study were at the lower end of the range of values reported in former studies (e.g. Bowen et al., 1998; Tank and Dodds, 2003, Collier, 2004; Smokorowski et al., 2006), but direct comparisons between the studies were difficult. Beside the fact that different laboratory methods for analysis of chl $a$ concentrations were used in the studies, the differences could be also explained by specific parameters of the sampling sites (lakes versus streams, fast versus slow flowing sites, dissolved nutrient concentrations and temperature, shading by canopy, grazing pressure by invertebrates) and the use of different wood substrates (small veneers, ice-cream sticks, dowels, wood blocks, natural branches), designs of incubation (depth of exposition, incubation in mesh bags, incubation near to the banks) and methods to remove biofilm from the wood surfaces (scraping, brushing, using whole wood piece).

ATP has been rarely used to characterise biofilms on submerged wood surfaces, although Kooij et al. (1995) showed that biofilm formation rates on surfaces can be obtained by ATP analysis as a function of time. 
Concentrations of ATP from epixylic biofilms reported in previous studies correspond well to our results (Golladay and Sinsabaugh, 1991; Sinsabaugh et al., 1991; Spänhoff et al., 2006). Remarkable were the relatively similar temporal dynamics of ATP in epixylic biofilms in the two streams, but interpretation of ATP dynamics in the present study is difficult as ATP values might not only represent the microbial biofilm. Scrapings from the wood surfaces could include beside bacteria and algae also superficially grown fungal hyphae as well as deposited organic matter and meiofauna components like protozoans, small nematodes, tardigrada and rotatoria. However, no significant relationships between chl $a$ and ATP concentrations in biofilms were found during the study period. Thus, ATP concentrations in biofilms seem to be more independent from those factors influencing algal biofilms.

Our results showed that epixylic biofilms on incubated branches in both streams were influenced by the stream type and the duration of incubation. No significant effect of invertebrate numbers on biofilm parameters during the whole study period could be detected but increasing invertebrate numbers during the first 55 days of incubation might have suppressed the initial biofilm development indicated by maximum concentrations of chl $a$ and ATP after peaks of invertebrate numbers on wood surfaces in both streams. Another factor likely influencing epixylic biofilm growth in the LMB was the flashy discharge regime, that often leads to a scouring of sand sediments negatively affecting surface biofilms by abrasion (Spänhoff et al., 2006). This effect of moving sand sediments on primary production has been also reported by Atkinson et al. (2008). However, the impact of discharge on biofilm and invertebrate numbers could not be evidenced by statistical analyses. Nutrient limitation of epixylic biofilm growth could be excluded for the LMB, due to high concentrations of dissolved nutrients during the whole study period, which is also expressed by up to $10 \times$ higher maximum chl a concentrations in the water column $\left(24.9 \mu \mathrm{g} . \mathrm{L}^{-1}\right)$ compared to the Loermecke $\left(1.9 \mu \mathrm{g} . \mathrm{L}^{-1}\right)$. The limited availability of dissolved nutrients most likely explain the lower chl $a$ concentrations of epixylic biofilms in the Loermecke. Low chl $a$ concentrations in the water column and slower mass loss of branches incubated in the Loermecke compared to the LMB (Spänhoff and Meyer, 2004) supported the nutrient limitation hypothesis.

\section{Invertebrate colonization of incubated alder branches}

Initial colonization of newly introduced substrates by invertebrates takes place very rapidly in streams (Mackay, 1992). This holds true for the present study in which invertebrate numbers peaked on introduced branches after 34 days in the Loermecke and 55 days in the LMB. The observed temporal pattern of colonization in both streams was characterized by rapid immigration (very likely by drift) and accumulation of mainly small individuals on branch surfaces during the first weeks of incubation.
Abiotic factors and competition regulating invertebrate numbers seemed to be of minor importance during this initial colonization period. Thereafter, invertebrate numbers decreased rapidly and fluctuated in both streams. Especially the number of small chironomid larvae and Nematoda decreased significantly in both streams. Additionally, the number of small nemourid and baetid larvae decreased in the Loermecke. The lowest numbers of invertebrates coincided with hydrological events typical for the two streams. Increased discharges were most common in the LMB during January to March which explains the lowest invertebrate numbers in the March samples. Thus, the decrease of invertebrate numbers on incubated branches in the lowland stream (LMB) coincided with a distinct increase in discharge. While the mean discharge during a three day period before the first three sampling dates ranged between 190 and 260 L.s ${ }^{-1}$, the mean value before the sampling date in January was 530 L.s ${ }^{-1}$ (Fig. 2). In contrast, extreme low flow events were common in the Loermecke during August and September as this stream is characterised by sections of karst geology. The very low number of invertebrates in the September sample was found during periods of very low flows (Fig. 2).

The composition of functional feeding groups was different between wood-inhabiting assemblages of invertebrates from the two streams. Grazers were dominant in both streams, but in the lowland sand stream the numbers of collectors was distinctly higher compared to the upland stream. This is reflected by the overall composition of invertebrates from the streams, as grazers are dominant in the gravel stream Loermecke and collectors inhabit preferably the sand sediment of the lowland stream. Taxonomic composition of wood-inhabiting invertebrate assemblages was different between streams as shown by multivariate statistics and explained by different physical properties of the stream types. The differences in the hydrological regime of the two streams lead to different temporal patterns of biofilm development and invertebrate colonization, but the main stages of "rapid initial colonization of an uncolonized substrate by invertebrates" and thereafter "reaching a state of moderately fluctuating equilibrium of invertebrate numbers" could be observed in both streams.

\section{Invertebrates inhabiting natural in-stream wood of lowland and upland streams}

Submerged wood from the streams displayed different assemblages of wood-inhabiting invertebrates. There was no clear pattern that separated lowland from upland streams, as each stream displayed a rather specific invertebrate fauna on submerged wood. However, sampling sites of neighbouring streams displayed mainly a higher similarity between taxonomic composition of invertebrates from submerged wood than sites that were more spatially separated. Nevertheless, multivariate statistics explained only a small percentage of variance between 
the samples. Number of sample replicates and a single sampling date were not sufficient for detailed statistical analysis of taxonomical differences between wood-inhabiting assemblages. The investigation of the wood-inhabiting invertebrate assemblages of the same streams during spring showed very similar results (Homermann, 2001). However, other factors that were not investigated during this and the unpublished study by Homermann (2001) might be as well important for the taxonomic composition of wood-inhabiting invertebrate assemblages as the stream type.

Overall, colonization density of invertebrates from natural in-stream wood was mainly lower compared to those from the incubation experiment. However, the differences became much smaller towards the end of the incubation experiment, when stream specific factors such as hydrology and interspecific competition controlled the numbers of wood-inhabiting invertebrates.

\section{Conclusion}

Indications for stream specific patterns of wood colonization by aquatic invertebrates and biofilm development were found. First of all, newly introduced wood is rapidly colonized by invertebrates in both stream types, but the very high colonization densities that were reached rapidly after incubation of the branches did not represent the colonization densities of invertebrates on long-term submerged wood. This should be considered for the time scale of future studies on invertebrate colonization of experimentally incubated wood in streams. Secondly, colonization of submerged wood by invertebrates seemed to be strongly affected by the hydrological regime of the stream.

Patterns of epixylic biofilm development were different between the two stream types, as algae, bacteria and other biofilm components depend on abiotic stream properties and biotic factors like invertebrate feeding. The temporal and spatial variability of epixylic biofilms in different streams seems to be so high, factors affecting the woodinhabiting biocoenosis so diverse and abiotic and biotic interactions so complex, that it is very difficult to draw general conclusions on colonization patterns of biofilms on submerged wood in streams.

The present study gave some evidence that the initial phase of invertebrate colonization are similar for different stream types, but this was tested for undecayed branches of rather uniform length and shape in two streams, only. In-stream wood samples, that covered a larger range of wood substrates in different stages of decay showed a large heterogeneity of invertebrate assemblages in streams which stresses the important role of submerged wood for species biodiversity in stream ecosystems.

Acknowledgements. Many thanks to Gudrun Schulze for her support in laboratory work and collecting of invertebrates from the in-stream wood samples. The manuscript was greatly improved by many helpful advices of two anonymous reviewers.

\section{References}

Atkinson B., Grace M.R., Hart B.T. and Vanderkruk K.E.N., 2008. Sediment instability affects the rate and location of primary production and respiration in a sand-bed stream. J. N. Am. Benth. Soc., 27, 581-592.

Benke A.C. and Wallace J.B., 2003. Influence of wood on invertebrate communities in streams and rivers. In: Gregory S.V., Boyer K.L. and Gurnell A.M. (eds.), The ecology and management of wood in world rivers, American Fisheries Society Symposium, 37, Bethesda, Maryland, 149-177.

Benke A.C., van Arsdall T.C. and Gillespie D.M., 1984. Invertebrate productivity in a subtropical blackwater river: the importance of habitat and life history. Ecol. Monogr., 54, 25-61.

Biggs B.J.F., Smith R.A. and Duncan M.J., 1999. Velocity and sediment disturbance of periphyton in headwater streams: biomass and metabolism. J. N. Am. Benth. Soc., 18, 222-241.

Bond N.R., Sabater S., Glaister A., Roberts S. and Vanderkruk K., 2006. Colonisation of introduced timber by algae and invertebrates, and its potential role in aquatic ecosystem restoration. Hydrobiologia, 556, 303-316.

Bowen K.L., Kaushik N.K. and Gordon A.M., 1998. Macroinvertebrate communities and biofilm chlorophyll on woody debris in two Canadian shield lakes. Arch. Hydrobiol., 141, 257-281.

Cleven E.J., 1999. An improved method of taking cores in sandy sediments. Arch. Hydrobiol., 147, 65-72.

Cleven E.J. and Meyer E.I., 2003. A sandy hyporheic zone limited vertically by a solid boundary. Arch. Hydrobiol., 157, 267-288.

Collier K.J., 2004. Invertebrate community dynamics in softbottomed streams of northern New Zealand: a spatiotemporal hierarchy. New Zeal. J. Mar. Fresh., 38, 1-18.

Collier K.J. and Halliday J.N., 2000. Macroinvertebratewood associations during decay of plantation pine in New Zealand pumice-bed streams: stable habitat or trophic subsidy? J. N. Am. Benth. Soc., 19, 94-111.

Eggert S.L. and Wallace J.B., 2007. Wood biofilm as a food resource for stream detritivores. Limnol. Oceanogr., 52, $1239-1245$.

Elosegi A., Diez J.R. and Pozo J., 1999. Abundance, characteristics, and movement of woody debris in four Basque streams. Arch. Hydrobiol., 144, 455-471.

Elosegi A., Diez J.R. and Pozo J., 2007. Contribution of dead wood to the carbon flux in forested streams. Earth Surf. Process. Landforms, 32, 1219-1228.

Giller S. and Malmqvist B., 1998. The Biology of Streams and Rivers, Oxford University Press, Oxford, 296 p.

Golladay S.W. and Sinsabaugh R.L., 1991. Biofilm development on leaf and wood surfaces in a boreal river. Freshw. Biol., 25, 437-450.

Gulis V., Suberkropp K. and Rosemond A.D., 2008. Comparison of fungal activities on wood and leaf litter in unaltered and nutrient-enriched headwater streams. Appl. Environ. Microbiol., 74, 1094-1101.

Hax C.L. and Golladay S.W., 1998. Flow disturbance of macroinvertebrates inhabiting sediments and woody debris in a prairie stream. Am. Mid. Nat., 139, 210-223.

Hoffmann A. and Hering D., 2000. Wood-associated macroinvertebrate fauna in Central European streams. Int. Rev. Hydrobiol., 85, 25-48. 
Homermann A., 2001. Untersuchung zur xylobionten Makroinvertebratenfauna verschiedener Fließgewässertypen. Unpublished thesis, University of Muenster, Germany, 97 p.

Johnson Z.B. and Kennedy J.H., 2003. Macroinvertebrate assemblages of submerged woody debris in the Elm Fork of the Trinity River, Texas. J. Freshwater Ecol., 18, 187-197.

Kail J., Hering D., Muhar S., Gerhard M. and Preis S., 2007. The use of large wood in stream restoration: experiences from 50 projects in Germany and Austria. J. Appl. Ecol., 44, 1145 1155.

Kiffney P.M., Richardson J.S. and Bull J.P., 2003. Responses of periphyton and insects to experimental manipulation of riparian buffer width along forest streams. J. Appl. Ecol., 40, 1060-1076.

Lester R.E. and Boulton A.J., 2008. Rehabilitating agricultural streams in Australia with wood: A review. Environ. Manage., 42, 310-326.

Mackay R.J., 1992. Colonization by lotic macroinvertebrates: a review of processes and patterns. Can. J. Fish. Aquat. Sci., 49, 617-628.

Magana A.M. and Bretschko G., 2003. Retention of coarse particulate organic matter on the sediments of Njoro River, Kenya. Int. Rev. Hydrobiol., 88, 414-426.

Millington C.E. and Sear D.A., 2007. Impacts of river restoration on small-wood dynamics in a low-gradient headwater stream. Earth Surf. Process. Landforms, 32, 1204-1218.

Nusch E.A., 1999. Chlorophyllbestimmung - photometrisch. In: von Tümpling W. and Friedrich G. (eds.), Methoden der biologische Gewässeruntersuchung Fischer Verlag, Jena, Germany, Band 2, 368-375.

Pereira C.R.D., Anderson N.H. and Dudley T., 1982. Gut content analysis of aquatic insects from wood substrates. Melanderia, 39, 23-33.

Robertson A.I., Bacon P. and Heagney C., 2001. The responses of floodplain primary production to flood frequency and timing. J. Appl. Ecol., 38, 126-136.
Sabater S., Gregory S.V. and Sedell J.R., 1998. Community dynamics and metabolism of benthic algae colonizing wood and rock substrata in a forest stream. J. Phycol., 34, 561-567.

Schmedtje U. and Colling M., 1996. Ökologische Typisierung der aquatischen Makrofauna. Informationsberichte des Bayerischen Landesamtes für Wasserwirtschaft, 4/96, 1-543.

Sinsabaugh R.L., Golladay S.W. and Linkins A.E., 1991. Comparison of epilithic and epixylic biofilm development in a boreal river. Freshw. Biol., 25, 179-187.

Smokorowski K.E., Pratt T.C., Cole W.G., McEachern L.J. and Mallory E.C., 2006. Effects on periphyton and macroinvertebrates from removal of submerged wood in three Ontario lakes. Can. J. Fish. Aquat. Sci., 63, 2038-2049.

Spänhoff B. and Meyer E.I., 2004. Breakdown rates of wood in streams. J. N. Am. Benth. Soc., 23, 189-197.

Spänhoff B., Alecke C. and Meyer E.I., 2001. Simple method for rating the decay stages of submerged woody debris. J. N. Am. Benth. Soc., 20, 385-394.

Spänhoff B., Reuter C. and Meyer E.I., 2006. Epixylic biofilm and invertebrate colonization on submerged pine branches in a regulated lowland stream. Arch. Hydrobiol., 165, 515-536.

Tank J.L. and Dodds W., 2003. Nutrient limitation of epilithic and epixylic biofilms in ten North American streams. Freshw. Biol., 48, 1031-1049.

van der Kooij D., Veenendaal H., Baars-Lorist C., van der Klift D.W. and Drost Y.C., 1995. Biofilm formation on surfaces of glass and teflon exposed to treated water. Water Res., 29, $1655-1662$

Ward G.M. and Aumen N.G., 1986. Woody debris as a source of fine organic matter in coniferous forest stream ecosystems. Can. J. Fish. Aquat. Sci., 43, 1635-1642.

Webster J.R., Benfield E.F., Ehrman T.P., Schaeffer M.A., Tank J.L., Hutchens J.J. and D'Angelo D.J., 1999. What happens to allochthonous material that falls into streams? A synthesis of new and published information from Coweeta. Freshw. Biol., 41, 687-705. 